\title{
An outline of ancient silk route in central Asian region: Reference with Buddhism
}

\author{
Archana Gupta*
}

School of International Studies, Jawaharlal Nehru University, New Delhi, India

\section{Keywords \\ Buddhism \\ Central Asia \\ Silk route \\ Proselytize \\ Monasteries}

Received: 6 September 2019

Accepted: 11 November 2019

Published: 12 March 2020

\begin{abstract}
This study investigates how Buddhist monks and pilgrims, who appeared to spread the practice trip to the Asian regions, played an important role in connecting assisted. Through which way thousands of monasteries dotted in the Eurasian continent had to ensure peace and prosperity. The study follows a historical, descriptive, and analytical approach. The study employs theoretical insights from the cultural, international relations, regional, and historical aspects. Data sources include reports, press statements, government documents, books, journals, articles, magazines, internet sources, newspapers, unpublished research documents and other relevant materials. It is highlighted that there is no attention given to revive Buddhism through the new Silk Route. The study concludes that the restoration of the Silk Route may help to some extent in solving the socio-economic, political, and cultural problems. It would promote the development of regional cooperation within Central Asia.
\end{abstract}

\section{INTRODUCTION}

"Silk Route" was a term initially used by Ferdinand Von Richthofen, a German geographer, in the 19th century A.D while referring to a prehistoric trunk street crossing Central Asia (Rhie, 2003). The term 'Silk Road' portrays the trade course between China and Central Asia. The story begins in around 100 B.C when an overland trade course network was created to convey goods between Europe and Asia. The Silk Route passes through Central Asia and covers 6,400 kms; it is the first ever diplomatic and transcontinental trade road that connects Far East and China with India and Europe. It is a road network following different contacts amongst the residents of Mediterranean countries, around Central Asia, and the Middle East, Eastern part of Asia and the Indian subcontinent. The oldest, immediate and the most commonly utilized route were named as the Silk Road, where valuable Chinese fabrics were exchanged in abundance. Throughout the Middle Age, the road, extending over 4000 miles, served as the main communication channel among East and West.
In the late 15th Century A.D, preceding the sea route discovery among Europe and Asia, the overland routes were steadily relinquished for maritime trade. The "Oasis Route" a connection between semi-desert zones in Central Asia and caravan cities in the desert; the "Steppe Route", a commercial course dominated by the nomadic tribes - who were dwelling in the Eurasian region of steppe, that stretches towards the northern Oasis Route; and the "Southern Sea Route", a connection between the Arabia Sea, Indian Ocean, the Red Sea, China Sea, and the Mediterranean Sea; together these routes form 'The Silk Route'. The Old Silk Route Silk Route wasn't a single route but it was the courses, paths, and roads together going towards the east-west direction. Many courses were properly developed and were comparatively secured; whilst the others had lesser levels of protection and oasis towns that could help avoid people from bandits. Along Taklamakan's southern edge there was a route that was very volatile, yet a shorter one. Kashgar (Kashi), became a significant trade center in Central Asia, as it was a

${ }^{*}$ corresponding author: Archana Gupta

†email: arachanag.jnu@gmail.com 
meeting point for all the paths on the Silk Roads.

The "Oasis Route" was the main pathway and not only well-known for its historical importance considering the exchange of cultural values and East-West trade, but also due to the evolution of this route which sees numerous travelers passing on the route over the century. The Oasis Route terminals were: In the east, it had Changan (Xian) and in the west it had Rome; and afterward it had Luoyang in the East and Byzantium (Constantinople) in the West (Exhibition, 1988; Suharti \& Pramono, 2016; Yazici, 2016). The course traveled across several dangerous areas like the Taklamakan desert, the Tien Shan and Kunlun Shan, the Pamirs, the Karakum and Kyzylkum deserts, and the Hindu Kush. The Taklamakan dessert was named as "the Land of Death" or "the Land of Irrevocable Death" by the locals. Oases of different sizes existed at the bottom of steep mountains. Cities, enclosed by farmlands, greenery, and orchards with ponds surrounded by flower beds, were built in the oases and were secured by walls and gates. Various travelers from other lands came together in the oases to make a marketplace arrangement of different types such as an open-air trading market where people could trade their local goods. The people of oasis cities created a caravan and were involved in intermediary activities of the East-West exchange. The "Oasis Silk Route" is an enormous mark of human activity, where they overcame natural risks and uncertainties for a thousand kilometers distance. It later evolved as the shortest route which went through Central Asia and connected the East and West. The Oasis Silk Route's four thousand kilometers long segment is situated in Asia's center and go from the Eastern and the Western side of Turkistan (Exhibition, 1988). Initially people had to combat various natural hazards, such as the huge stretch of deserts, hills blanketed by snow with cold winds sweeping by, relentless mountain streams with deep valleys, and steep cliffs. Even they feared evil spirits, bandits, and highway thieves.

The Oasis Route was risky when compared to the Steppe Route, still, numerous travelers chose this route risking their lives for travel, this included- kings, army generals, soldiers, aristocrats, merchants, local governors, artists, Buddhist monks, artisans, missionaries, scholars, exiles, refugees, musicians, and dancers. A possible reason for this could be that the nomadic tribes there, restricted access, and the route had a deficit of towns, markets, and provisions for accommodation. It lacked the supply of food, water, and even other travel necessities; medical aid and entertainment could be availed by travelers and caravans along the course. Market provisions and accommodation facilities for caravans and travelers were maintained in the caravan city-states near the Oasis Route. The Steppe Route was the second most significant factor of the Silk Route. Nomads utilized this route to move from east to west or vice-versa and for protecting their cattle's fodder. The relocation of the nomadic custodian tribes of cattle in ancient times led to the origin of the Steppe Route; later these nomadic equestrian tribes made improvements in metal culture which was commonly known as Scytho-Siberian style that spread in the East and in the West through the Steppe Route. metal culture and Steppe-Route was burrowed by the pre-historic nomadic equestrian tribes, facilitating the later transmission. In Northern Eurasia, the Steppe Route was more than a road it was an extension of plains from east to west that acted as a truck road of traffic. It had become a mobile truck road which facilitated the nomadic equestrian tribe migration to any place, for trade or cattle breeding. It was a fertile pasture as well as a platform for military tasks. It evolved in to a huge economic and cultural channel which was used for the exchange of products, from East and West; and brought in, global information and technology in Central Asia to the nomadic equestrian tribes. The Steppe route enabled the relocation of the equestrian nomads dwelling in Eurasia and acted as a natural highway that facilitated the transmission of gold culture, nomadic lifestyle, and animal patterns, on the East and West side.

The outlet of Southern Sea Route was the 3rd large mark on the Silk Route for connecting the Orient and Occident, in terms of politics as well as culture. Central Asia and the Parthian lands were not the only reasons for the availability of silk in Europe; it could also be brought from a few remote ports in India. The Southern Sea Route was found using the wind to help mariners on their route, and a Roman pilot made it possible by finding a direct route across the Indian Ocean. Southern Sea Route began on China's South coast in Kuangchou (Canton), surrounding the Indochinese peninsula, passing through the Malacca Straits and traveling up to the opening of Ganges. The Archaeological excavations differentiate among the products from southern China which came through north-east India and among those from northern China which came through the Central Asian route. Toward the ending of the 1st century A.D silk was imported in bulk by the Mediterranean countries and was transported by sea and not by using the land route through Persia (Boulnois, 1963).

\section{Locality of Silk Route}

Major part of the world was covered by The Silk Route, known initially. From Changan (literally, eternal peace) (Marylin, 2010), which is today known as Xian, China's for- 
mer capital during Chi, Han, Sui, and Tang empires; going through the prime route, Kansu, separated at Anxi near Dun Huang; its north stream passed popular oases such as Turfan, Urumqi, and Hami; after which, it either traveled west towards the region in IIi and the Caspian Sea or streamed along the south to Korla, Kucha, Aksu, and Kashgar; the route encircled the northern side of the Taklamakan desert (Tarim Basin); its south stream passed Dun Huang, Niya, Keria, Khotan, Karghalik, and Yarkand (Shache) and met the north stream at Kashgar (Shafi, 1988). There has been another middle course that went westwards traveling from Dun Huang to Lop Nor from Yumen Pass (The Jade Gate), traveling alongside the Great Wall to Loulan and subsequently it might have traveled in the North West direction to meet Korla's Northern stretch or South West to meet Jechiang's (Shanshan) South stretch; in Kashgar, the meeting point of 2 prime courses, it split again; the western stretch kept moving, traveling above the Roof of the World (Pamirs) toward Samarkand, Nissa, Bukhara, Merv, Balkh, and then passing from Parthia Mediterranean shores at Antioch and Rome, then sailing towards Alexandria; the southern road took a turn alongside Tashkurghan passing the Karakoram pass moving towards the great Buddhist University of Taxila or towards Gandhara (Tucker, 2003). There have been other courses as well, going to Leh from Yarkand or Khotan and in Kashmir towards Srinagar and the other over the Taghdumbash Pamirs, passing Wakhan towards Iran and Afghanistan. The Silk Road is primarily bifurcated into three sections: Xian to Dunhuang, Taklimakan Desert to Kashgar, and beyond Kashigar. It commences from Changan (now a day's Xian), moves westwards via Lanzhou, Hexi Corridor, and divides at Dunhuang from the south and north of Taklamakan Desert. The south street travels through Dunhuang, Hami, Turfan, Korla, Kuche, and Kashgar, and the north street travels through Dunhuang, Cherchen, Khotan, Yarkand, and Kashgar. They then meet at Kashgar, within the China borders. Leaving Kashgar, the primary route travels across the Pamirs into Central Asia, splitting into 2 courses of south and north. In the ancient times, the two routes are named as Irkeshtam Pass and the Torugart Pass. The previous course travels through Pamirs and Ferghana valley and keeps moving in Uzbekistan passing through Kokand, Tashkent, Samarkand, and Bukhara, getting to Turkmenistan, later arriving at Mashhad in Iran. The Silk Road separated into the south road and north road. The south road passes through 3 nations - Iraq, Egypt and Syria. The last halt was at Egypt in the Alexandra City. The north road travels to Istanbul in Turkey (Tucker, 2003).

\section{RESEARCH METHODOLOGY}

The study follows historical, descriptive and analytical approach. The study employs theoretical insights from culture, international relations, regional, and history aspect. The study is based on available primary and secondary sources. The primary sources include reports, press statements, government documents. The secondary sources such as books, journals, articles, magazines, internet sources newspapers, unpublished research documents and other relevant materials are utilized in carrying out the research work.

\section{HISTORY OF THE DEVELOPMENT OF THE GREAT SILK ROUTE}

Silk Route's western end seems to have improved before the eastern end. The Persian Dynasty dominated a huge bundle of the Middle East, outstretching up to the Indian kingdoms on the east. When Alexander the Great captured this region unto Fergana on the modern Xinjiang regions border in China, trade among various parts of the dynasty had begun to persuade the cultures in these areas. In 329 B.C, he established the Alexandria city, here. In Central Asia during the next three centuries, the Greeks lived and expanded persistently eastwards. In the first century B.C, a historic Greek Strabo mentioned in his writings that the dynasty spread up to the Seres [China]. Some historians assume that Euthydemus (230-200 BC) of Bactria, the eastward region of Persia, could've steered expeditions up to the Chinese Turkestan's Kashgar; ensuring China's first official contacts with the West.

The formation of marital pact among the Han dynasty's princess (206 B.C.E.-CE 220) and pastoral nomadic tribe's Shanyu, also called as Hsiung-nu (Huns' predecessors) their animals were tended in modern Mongolia and south Siberia as per Chinese sources. An exchange with China was the groups' requirement and when such business was not accepted they became very aggressive. Ecological emergencies could have triggered them to attack Chinese pact to get the required goods. The Hans claimed as self-sufficient - economically, attempted to restrict the commercial and diplomatic relationship with people who were perceived as "barbarians". Around 139 B.C, the Han king of China was trying to determine the need to look for assistance against the bellicose neighbors; thus, Wu-ti directed Chang-Chien to go to Central Asia to establish this kind of association (Rossabi, 2009). Chang via the oases and towns which would eventually be a part of the Silk Road and arrived in Central Asia; however, his efforts to protect the allies were dismissed. Chang's ultimate job had failed still he gained 
a lot through the 13 years of expeditions. In this time period, he was imprisoned by the Hsiung- nu. Chang broke out from the prison and was confined on his way back; however, he finally managed to return and give a report to the ruler. Chang's mission as advised by Historians was more of "an intelligence mission staffed with expendable personnel" and less of an embassy business (Torday, 1997). Chang gave to $\mathrm{Wu}$-ti some alluring trade opportunities with the western land. However, Chinese merchants in a few years were undergoing the tough journey towards the west passing from the Gansu corridor, around the Taklamakan desert boundaries into Central Asia.

In the subsequent years, trade flourished. Wu-ti was interested in procuring horses, especially from Ta-yuan, possibly the Farghana Valley, a place visited by Chang. The mounts were called the "heavenly horses" by the Chinese (Rossabi, 2009). The Ta-yuan people were resistant to give the horses, but in 104 B.C the ruler of Han instructed Li Kuang-li, a general head of the huge army, to forcefully obtain these horses. But what restrained their journey was the dearth of required necessities which led to the starvation of the army. But Wu-ti strengthened and managed to succeed in obtaining submission from the residents of Ta-yuan. The Chinese could bring along only 30 "heavenly horses", however, the course of trade had clearly opened and the Han Dynasty dominated its eastern part. China had linked with west with Tran- Asian land route; even before the Han Dynasty (silk has been found in Egypt since around 1000 B.C and in Europe around 300 years later) (Wilford, 1993) but Han's efforts gave a risky and lengthy Trans-continental journey in one trip. Silk and other valuable goods in the neighboring states were in the power of various economic and political systems.

\section{Silk Route Linkage with Central Asia and India in Kushan's Period}

The Kushanas was a part of a group the great Scythia race of North-west China. Kanishka was the greatest king of Kushanas who embraced Buddhism and encouraged the same in his kingdom. The 4th Buddhistcouncil was held, as per the Sarvasitvada tradition, with Kanishka's support, and the Mahavibhașa, a great commentary about the Sarvasitvada School, was compiled. Gandhari Buddhist writings from the Kushana Empire were probably a part of the first Buddhist literature which came to China in the 1st or 2nd century CE. According to scholars, many Chinese translations of the Buddhist writings were originally in Gandhari, and initial translators working in China are mainly from the Kushana origin (Beckwith, 2009). The Great Silk Route was laid on the land of the Kushans and the Parthians from China to the Mediterranean Roman Empire; in the human history, it was the first transcontinental trade and diplomatic course. The chief course of trade from India traveled to Taxila, passing from Khyber Pass to Bamiyan and across the Hindu Kush to Balkh. From Balkh, the truck road led eastwards on the Wakhan corridor and passing through the Pamirs towards China or north towards Termez and coming towards Central Asia. Bamiyan wasa junction of a strenuous journey across the country. At this parts' eastern end of the Silk Road is the Khyber Pass which rises through the foothills of the Sulaiman range fromthe beginning, around $1 \mathrm{I} 6 \mathrm{~km}$ west of Peshawar. The $45 \mathrm{~km}$ stretched pass provides access to India since the beginning of history, that has been recorded during the great Kushan King Kanishka Dynasty (Tucker, 2015).

During the Kushanas reign, they took the war of the oases of the Tarim. China dominated the east part of this great course. The rise of these two powers over smaller states in the region enabled caravans during this period to work peacefully and securely. Garrisons could be seen everywhere. The period was highly favorable for trade. Under the sphere of the Indo-Scything Kingdom's influence fell 3 western oases of the Kushans. Chinese garrisons who were isolated collaborated together along with the locals and the Kushans representatives to form a united front against the Huns; so as to ensure the continuation of trade. There was a pact among China and the Kushans Empire because of which Pan-Ch'ao directed an ambassador to Rome; he along with his entire suite had a trouble-less journey through the Kushans territory. Maintaining good relations between both the empires was necessary: the Chinese were looking for allies against the Tibetans and the Huns while the Kushans were foreseeing trouble with the Persians in the west (Azarpay, 1970). As per historical records, the Kushans and Chinese had serious disputes: a rejected proposal of marriage. In A.D 90 the Emperor of Kushans directed an ambassador to China' court to ask the hand in marriage of a Chinese princess, on behalf of his sovereign. However, the ambassador ceases by the commander of the Western Territories with no intention of letting the visitor execute such an impudent project. It was possible for the Chinese to sell their silk to the Persians or the Kushans, and the marriage proposal could've been to secure a monopoly of silk purchase and resale; this would've been turbulent for the Persians. Thus, refusing the Kushan was China's way of expressing interest in an alliance with Persia. Persia won in this struggle and benefited by its alliance with Chinese. At the center of the Kushan Empire was the Gandhara re- 
gion where a multiethnic society that was unprejudiced to religious differences, resided. Its geographic position which gave direct access to the overland silk routes and links to the Arabian Sea ports, Gandhara was defeated and ruled by the Mauryans, Alexander the Great (327-325 B.C.), his IndoGreek successors (third-second centuries B.C), and a combination of Scythians and Parthians (2nd and 1st centuries B.C).

The mingling of people produces an eclectic culture which was descriptively expressed during the Kushan period, in the visual arts produced. The Kushan King directed ambassador to Rome due to the trade agreement between China and Persia. The Kushans kingdom was looking forward to forming an association with Rome because of its differences with China. Thus, Rome and Kushans came to common grounds and involved in a direct trade. During the Kushan period, people of the East started appreciating the advances of cultural relationships and connections; hence, they started building a community of culture with common cultural values for everyone living in the great empire. A significant feature of these economic and cultural connections, made along the Great Silk Route, was that every culture conserved its local tradition, original character, and national identity in the process of cooperation (Basham, 1968).

\section{Silk Route under the Han Empire (206BC- 200AD)}

The improvements in the trade course of Central Asian led to concerns for the Han Emperors in China. Crooks benefited from the terrain to raid the trade caravans across the Gansu Corridor. Hence, trade started suffering huge losses due to lesser merchants. Han rulers handled these threats by building forts and protective walls alongside the course. Later these segments were merged to make the 'Great Wall'; that holds on to its firm foundation even today, testifies human achievement. Later the Han Emperors understood that laying the foundation of a permanent local government was necessary in order to dominate course, especially the Taklamakan area. As soon as the local government would secure its place in the Taklamakan area, the growth of the settlements along the course started to plunge. Under the safety provided by the Han Dynasty, the settlements reaped the benefits of reliable and assured trade. Additionally, they immersed in the local culture and those cultures which were passed along the course. Along the Silk Route, mainly in the oasis region, there were various settlements were arranged during the Han Empire (206 B.C-A.D 220. The settlers gained due to the passing trade and immersed into the local culture and the other cultures encountered through busi- ness. Certainly, the locals escorted the caravans through the risky sections of the course. The local government at Wutai was founded near the Kuqa, Taklamakan's northern border, by the Han Dynasty to safeguard the states in this region, around 50 in that period. Collaterally, the Gaochang city was built in the Turfan basin. The city evolved into Huihe Kingdom's center; these people then constituted the Uygur minority in the area. In 115 B.C, Wudi directed the 1st Chinese embassy to the court of the Parthian King Mithridates II into Anxi (Persia) (Tucker, 2003). There were commercial objectives and the Parthian ruler responded courteously. As per various historians, this operation facilitated China's trade connections with Persia and then the Chinese silk purchase.

In the following years, the Parthians dazzled the Romans with their embroidered silk banners, imported from China. In 104-102 B.C and 42 B.C. the Han army in Central Asia campaigned through the Pamirs up to the west till Sogdiana and Ferghana, opening the Silk Road further. In the historical backdrop of the Han Empire, the 42 B.C campaign has been described elaborately; an event where the siege was laid to a closed settlement in Sogdiana, possibly by the Talas River. Xiongnu were the defenders however, the security of the agreement was ensured with the use of wooden railings, a Roman favored design which was not known to the East before the event. According to the sinologist Homer Dubs (Dubs, 1957), the Xiongnu defenders got assistance from the Roman soldiers and the prisoners were taken to Carrhae's Battle and later they were sent as slaves to the East. 145 Roman soldiers were captured by the Chinese, post victory; as this was China's first contact with the Romans, these prisoners were taken back (Tucker, 2003). At Xian, with the entry of foreigners, improvement in commerce with the West had mutually begun; foreign influence on the art could be yet another reason. When China extended its boundaries in Central Asia, traders and delegates started visiting China to show loyalty towards the Han court and gave their tribute with some exotic goods. Chinese merchants participated in various westward expeditions and improved trade and cultural interchange process. Technical innovations came to the Han Empire from its neighboring nations via Silk Road. Merchants, to secure a beneficial reception for their goods, often pretended to be emissaries of the Han court.

During the Chengdu rule (33-37 B.C) all the envoys who had gathered for a eulogy to the Han were from various merchants groups at different regions. From 73 A.D onward General Ban Chao (31-103 A.D) of the Han Empire started the restoration of the Han Dynasty in Central Asia. Till 91 A.D, many states in the Tarim Basin capitulated to the Han 
rule through Ban Chao's method with the local troops at a low expense. It empowered China to dominate the Silk Road again. During the same time, he designated "Protector General of the Western Region" (Tucker, 2015) and guided an exploration along Central Asia up to the Caspian Sea. An envoy named Gan Xing was directed to visit Da Qin (Rome) by Ban Chao. Gan Xing's journey in 97 A.D was obstructed and he conserved Parthians lucrative role, as an intermediary, in the Silk trade among China and Rome. China was referred to as the "land of Seres", (Liu, 2011) a nation which produced silk by mixing it Roman trees; the Chinese felt that Romans had physical similarities with the Chinese and that they referred as 'Great Qin' after China. During the Han reign, in the first century A.D, was when China's trade with the West evolved. Hou Han Shou (a Han historian) cued the development of peasant colonies on fertile lands and inns; founding posts to change horses along the main courses; couriers and messengers would travel in all the seasons through the year and stranger merchants would knock on the gates every day. Han dynasties trade and commerce with the neighboring regions had an effect on the art. The prevailing ideas like tackling animals or lace narratives and landscapes, originally taken from Steppe art, can be seen on Chinese harness fixtures and bronze belt plaques. These are taken from trade activities with the Xiongnu.

During the 7th century, Xuan Zhuang, a Chinese traveler, passed through the area on his way to India, for acquiring the Buddhist scriptures. On his journey outside, he was led by the northern branches of the Silk Road around the Taklamakan and got back through the southern route to the Tang capital at Xian. Chinese still consider him as a significant power in the overall development process of Buddhism in China; his voyages were adapted in the well-known classic play named "Tales of a Journey to the West" (Rhie, 2003). During the initial establishment of the Silk Road, silk wasn't the basic commodity. The Han Empire benefited from it before it interested the Romans and consequently, trade was encouraged bringing in a flush of large profits. The Romans loved silk to an extent where they would barter silk, in weight, with gold. On the Silk Road during the Tang Empire, 30\% trade included silk. During the Tang Empire, the art and civilization of the Silk Road reached its peak.

\section{The Apogee of Central Asia and the Silk Road during the Reign of Mongols}

The ortaq, the first international trade and taxation system was established by the Mongols, or at least patronized, (Allsen, 1989) and Endicott-West (1989). It was an association of merchant, run majorly by Muslims; the services included money lending services for caravans and other enterprises as well as tax-farming services for the emperors. It was lucrative, partially because of a government interest subsidy (Rossabi \& Langlois, 1981; Rossabi, 2009). Government policies, towards the ortaq, changed from eager participation and overindulgence, (as under Ogedei) to strict control (as under Mongke) based on the administration in power (Allsen, 1989). The empires' openness to commerce and the unprecedented security expected by merchants and craftsmen attracted businessmen from the 4 corners of Eurasia. Italian traders like the Polo family conducted a profitable business, traveling to and from the capitals of Mongol.

The high levels of wealth and culture in the eastern parts of Eurasia allured them. Marco Polo (1254-1324) started his journey towards Great Khanate in 1271 and stayed there for two decades; he returned home to Venice in 1295. In the due course of time, he narrated his story to a romance writer, Rustichello of Pisa, who penned it down and later published it (Moule, Pelliot, \& Polo, 1938). Rustichello's embroidered version of Marco Polo's report enchanted the Europeans to this day and ultimately he stimulated European sailors to find a direct course to the Orient. With every religion that the Mongols came across, as "pagans," they were the target of every organized religion. Delegates were directed to stimulate religion conversions among them and they persistently attempted to do so, although the Mongols lacked interest in all religions and sects; however, in time they embraced Tibetan Buddhism. The Mongol conquest was an important event in the history of the world; although according to the widely held view, the event was primary and formative, a watershed which segmented Eurasia before and after, doesn't count as historical evidence. Importantly, the main ethnolinguistic segmentations of Eurasia during the post-Mongol Empire period and those during the Pre-Mongol Empire period were in place and virtually remained unchanged until the twentieth century. The spread of a few practical constituents of the Chinese culture, as well as technology to Western Europe like gun powder 
and firearms, was certainly a side effect of the Mongol conquest. Western Europeans were stimulated to know more about the land described by Marco Polo, which was yet another side effect (Beckwith, 2009). The II-Khans could be referred to as art and science patrons. They constructed various mosques and took up other building projects, many of which have fallen into ruin.

The creation of "Persian" miniature paintings was a noteworthy accomplishment. Mongols brought various Chinese scholar-officials to run II-Khanest, smoothly, which further aided the development. The Chinese used a brush to write and paint and then started painting images for the Mongols and for each other. Muslims learned to create paintings in the Chinese style from them and imitated them; this led to the development of a hybrid style juxtaposing Byzantine art elements. Arabic calligraphy, the conventional Near Eastern styles along with Chinese style, altogether produced a great tradition of world art Islamic miniature painting. In return, the Yüan court, brought physicians, materia medica, astronomers, and other people/things from the Islamic world (Allsen, 1989). Samarkand was made the capital of Tamerlane. The walls, been torn down by the Mongols, were reconstructed, and the city was beautified with palaces, gardens, and religious buildings. The Samarkand improvisation continued which made it a model city and an alluring one; he decorated it partially with trophies taken from the conquered cities at the time of his campaigns and partially by patronizing the best artists as well as architects from his day. Various innovations characterize the architectural style of Timurid - the Central Asian ancestor of the Persian-Mughal style, could be found on buildings constructed during his time, popularly in his own mausoleum in Samarkand. Few of the world's greatest architectures and city plans belong to his reign and the immediate successors; the greatest Persian poet, Hafiz (Hafiz 1320-1390
A.D), who met Tamerlane and was honored by him.

\section{CONCLUSION}

The restoration of the Silk Route may help to some extent in solving the socio economic, political and cultural problems. It would promote the development of regional cooperation within Central Asia. Interest in the revival of the Silk Route began at the end of the 19th century. The discovery of ruins, ancient artifacts, buried cities and manuscripts attracted worldwide attention. The Silk Route today is a series of paved roads and train tracks that connect east to west along the paths of old caravan routes. The new Silk Route of the 21th century covers all modes of transportation including road, rail and sea as well as oil and gas pipelines and communication infrastructure.

\section{LIMITATIONS AND RECOMMENDATIONS}

The author believes that this study could be improved with more in-depth data collection and analysis. This study relied on secondary data; however, interviews of relevant officials and stakeholders could provide more deep insights. Thus, future studies are encouraged.

The current stage of dynamic development of political, trade and economic relations would be unthinkable without the strengthening of trust and mutually advantageous relations of partnership between all states. But with reference to Buddhism, there is no attention given to revive Buddhism through the new Silk Route. With the lack of Social and Cultural attention, there is no possibility in sight or substantial literature so as to revive Buddhism as was the case with the Old Silk Route. Buddhist culture is perennial and so is as fresh today as it was in the Buddha's time 2500 years ago. It is also self-sufficient, self-consistent, and self-sustaining. Based as it is on eternal verities, verifiable by individual experience, it is never obsolete. Nor does, its content change with context.

\section{REFERENCES}

Allsen, T. T. (1989). Mongolian princes and their merchant partners, 1200-1260. Asia Major, 4(6), 83-126.

Azarpay, G. (1970). The Kushan conference in Dushanbe. Archaeology, 23(3), 254-257. doi:https://doi.org/10.2307/ 503211

Basham, A. L. (1968). Papers on the date of Kanifka. London, UK: Brill Archive.

Beckwith, C. I. (2009). Empires of the silk road: A history of central Eurasia from the bronze age to the present. London, UK: Princeton University Press.

Boulnois, L. (1963). The silk road, translated by dennis chamberlin. London, UK: Ruskin House Press.

Dubs, H. H. (1957). A Roman city in ancient China. Greece \& Rome, 4(2), 139-148. doi:https://doi.org/10.1017/ s0017383500015916

Endicott-West, E. (1989). Merchant associations in yüan China: The" ortoy". Asia Major, 5(7), 127-154.

Exhibition, N. (1988). The grand exhibition of silk road civilizations. The Route of Buddhist Art, 4(6), 56-60. 
Liu, X. (2011). A silk road legacy: The spread of Buddhism and Islam. Journal of World History, 55-81. doi:https://doi.org/ 10.1353/jwh.2011.0021

Marylin, M. (2010). Kansu in the sixteen kingdoms period and inter-relationships with the Buddhist Art of Gandhara: The Western China in, early Buddhist Art of China and Central Asia, Asian Studies. Leiden, Netherlands: Brill Publication.

Moule, A. C., Pelliot, P., \& Polo, M. (1938). Marco polo: The description of the world. London, UK: Routledge \& Sons Limited.

Rhie, M. M. (2003). Aspects of the two colossal Budhas at Bamiyan. In Paper Presented in International Seminar on Xuanzang and the Silk Route, Indira Gandhi National Centre for the Arts, New Delhi, India.

Rossabi, M. (2009). Khubilai khan: His life and times. California, CA: University of California Press.

Rossabi, M., \& Langlois, J. D. (1981). China under mongol rule. New York, NY: Princeton: Princeton University Press.

Shafi, I. M. (1988). Silk road to sin kiang. Lahore, Pakistan: Wajidalis Publication.

Suharti, L., \& Pramono, A. (2016). Cultural intelligence among indonesian students: Role of international experiences and their impact on the development of social network and adaptive performance. Journal of Advances in Humanities and Social Sciences, 23(3), 182-194. doi:https://doi.org/10.20474/jahss-2.3.6

Torday, L. (1997). Mounted archers: The beginnings of Central Asian history. London, UK: University of Washington Press.

Tucker, J. (2003). The silk road: Art and history. New Delhi, India: Timeless Books.

Tucker, J. (2015). The silk road-China and the Karakorum Highway: A travel companion. London, UK: IB Tauris.

Wilford, J. N. (1993). New finds suggest even earlier trade on fabled silk road. New York, NY: New York Times.

Yazici, H. (2016). The art of opera in Turkey within the scope of culture-art policies. International Journal of Humanities, Arts and Social Sciences, 2(5), 159-164. doi:https://doi.org/10.20469/ijhss.2.20001-5 